J. Egypt. Acad. Soc. Environ. Develop., 16 (1): 13-24 (2016)

E.mail: easedjournal_egypt@yahoo.com

www.eased.byethost13.com
(D-Environmental Studies)

ISSN 1110-8770

eISSN 2314-5471 (online)

\title{
Evaluation of biopolymeric particulate organic carbon of phytoplankton from El Rayah El Tawfiki and El Rayah El Menoufy of Nile Delta, Egypt
}

\author{
Howayda H. Abd El-Hady \\ National Institute of Oceanography and Fisheries, \\ 101 Kasr Al Ainy, P.C. 11694, Cairo, Egypt \\ E-mail: Howayda999@hotmail.com
}

\begin{abstract}
The concentration and composition of the biopolymeric particulate organic carbon (BPC) of the major phytoplankton components (proteins, carbohydrates and lipids) were measured in the two Nile Rayahs El Tawfiki and El Menoufy. BPC along El Rayah El Tawfiki (4.32-18.59 $\mathrm{mgC} / \mathrm{l}$ ) was associated to the high extent of the biopolymeric $\mathrm{C}$ of proteins (4.73-18.36 $\mathrm{mgC} / \mathrm{l})$. While the biopolymeric $\mathrm{C}$ of carbohydrates ranged between 0.08 to $0.27 \mathrm{mgC} / \mathrm{l}$. The total concentration of biopolymeric $\mathrm{C}$ at $\mathrm{El}$ Rayah El Menoufy ranged from 6.19 to $15.42 \mathrm{mgC} / \mathrm{l}$. The maximum concentrations of BPC detected at some sites of El Rayah El Menoufy were related to the higher biopolymeric carbon in both proteins and lipids. The present results showed a maximum positive correlation between both carbonate and bicarbonate of water body of El Rayah El Tawfiki and El Rayah El Menofy and BPC of phytoplankton ( $r=0.9$ and 1). BPC of phytoplankton was strongly related to the fraction of biopolymeric $\mathrm{C}$ associated with phytoproteins $(r=0.79)$. Variations in the estimated biochemical components of phytoplankton at the investigated Nile Rayahs followed the trend: Proteins $>$ carbohydrates $>$ lipids which indicated the highest protein contribution to C-BPC in both studied areas. Lipids/carbohydrates ratio in the two studied regions ranged between 0.55 and 0.57 , which showed high nutritional value of organic matter in phytoplankton. Whereas, proteins/carbohydrates ratio ranged from 39.88 to 43.82, which indicated the aging of organic matter in phytoplankton. El Rayah El Tawfiki recorded higher energetic value $(127.86 \mathrm{Kcal} / \mathrm{l})$ than El Rayah El Menoufy $(124.45 \mathrm{Kcal} / \mathrm{l})$. This study demonstrated that fluctuation in phytoplankton composition due to the changes in carbonate and bicarbonate concentrations will have more impact on nutritional quality and biopolymeric carbon (BPC) of phytoplankton.
\end{abstract}

Key words: Phytoplankton, biopolymeric carbon, biochemical compounds, El Rayah El Tawfiki, El Rayah El Menoufy.

\section{INTRODUCTION}

El Rayahs El Tawfiki and El Menoufy are considered among the main irrigated canals of Nile Delta, Egypt (Talab et al., 2016). El Rayah El Tawfiki was constructed in 1889, it is regarded as one of the most ancient canals in Egypt, it's length is $192 \mathrm{~km}$ and irrigates 970,000 feddans. It crosses Qalyoubia, Dakahlia and Damietta Governorates. The average Water Quality Index (AWQI) at El Rayah El Tawfiki is about 70\% which indicates the exposure to human activities (Shawky et al., 2013). El Rayah El Menoufy supplement from Rosetta Brach and crosses El Mansoura and Zifta cities, its length $170 \mathrm{Km}$ (Ghannam et al., 2015).

Organic matter (OM) composition has been widely used to indicate the trophic state of the ecosystems (Cloern, 2001; Akhil et al., 2013; Renjith et al., 2013). Organic matter within water body is important in assessment of global biogeochemical cycles (Yamamuro, 2000; Goni 


\section{Howayda H. Abd El-Hady}

et al., 2003). The portion of OM and particulate biopolymeric organic carbon (BPC) has usually been assessed by the main biochemical contents (carbohydrates, proteins and lipids) of organic compounds (Fabiano et al., 1995; Dell'Anno et al., 2002; Pusceddu et al., 2009). Biochemical composition serves as a valid methodology for determination of the origin of organic matter (Colombo et al. 1996), also as an important tool to evaluate the nutritional quality of organic materials for consumer organisms (Rossi and Lardicci, 2002; Cividanes et al., 2002; Joseph et al., 2008). Ecological stoichiometry shows that the carbon content and the carbon-to-nutrient ratio of plant biomass are important biomarkers of ecological dynamics (Sudhakar and Premalatha, 2012). Carbon is the dominant element in organic matter, at moderate $\mathrm{pH}(>7)$ and temperatures $>30^{\circ} \mathrm{C}$, the dominant form of $\mathrm{CO}_{2}$ in water is bicarbonate (Sayre, 2010). $\mathrm{CO}_{2}$, $\mathrm{HCO}_{3}{ }^{-}$and $\mathrm{CO}_{3}{ }^{2-}$ can all serve as the source of carbon for algal growth and their production. Blue green algae growing autotrophically utilize the $\mathrm{HCO}_{3}{ }^{-}$and even $\mathrm{CO}_{3}{ }^{2-}$ ion directly (Becker, 1994). The size and biochemical composition of phytoplankton communities can be controlled by carbon fixation through the environment (Armstrong et al., 2002).

This study aims to: (i) evaluate variability in biochemical components and nutritional value of phytoplankton at El Rayah El Tawfiki and El Rayah El Menoufy (ii) assess the quantity and quality of particulate biopolymeric organic carbon (BPC) of phytoplankton in the two Nile Rayahs.

\section{MATERIALS AND METHODS}

Water samples were collected from one site of River Nile (RN) and 7 selected sites from each El Rayah El Tawfiki and El Rayah El Menoufy from spring 2014 to winter 2015 (Fig.1).

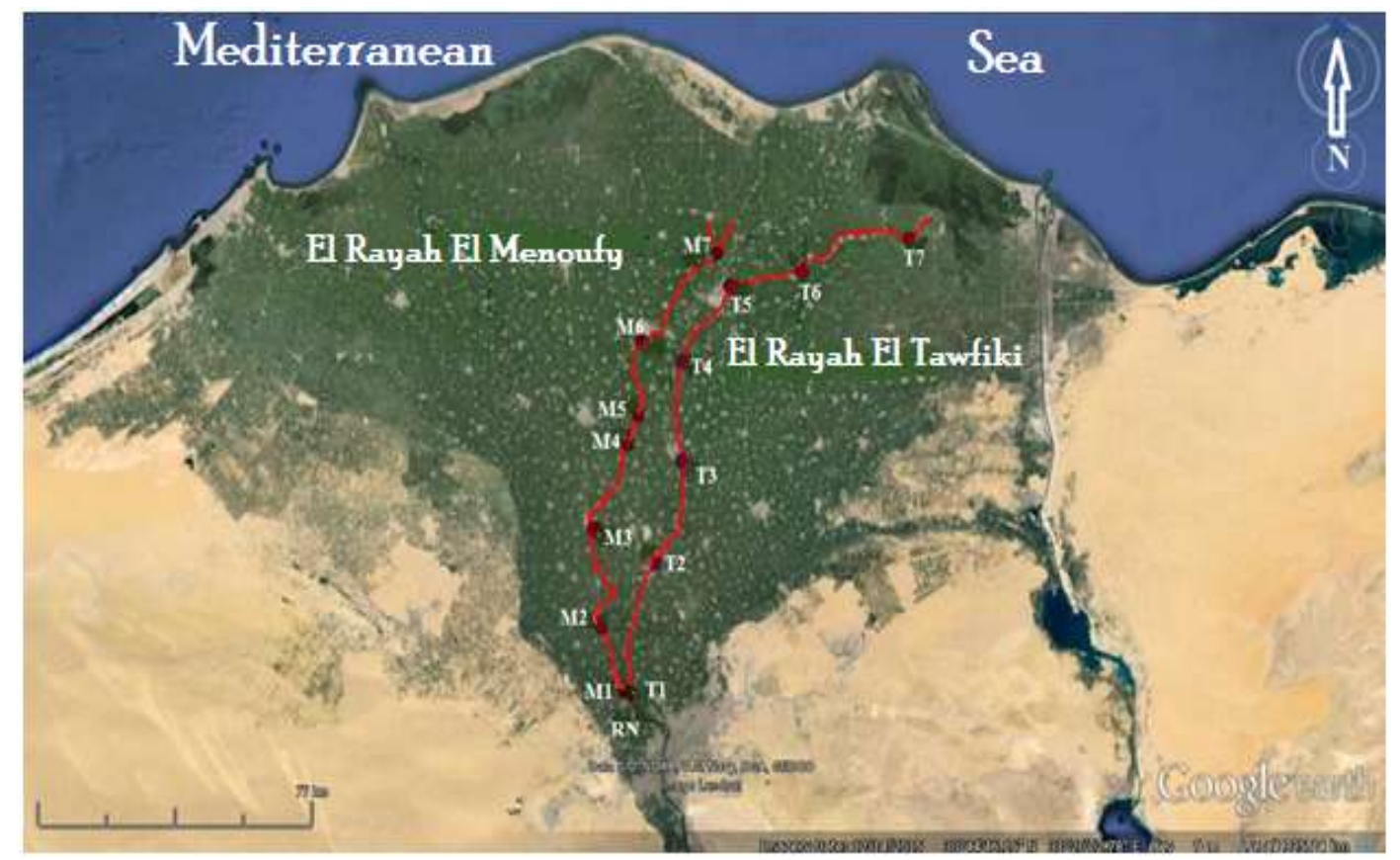

Fig. (1). Map of the study area showing the sampling locations. 
Evaluation of biopolymeric particulate organic carbon of phytoplankton from El Rayah El Tawfiki and El Rayah El Menoufy of Nile Delta, Egypt

\section{Description of the study area}

\section{1. El Rayah El Tawfiki:}

El Rayah El Tawfiki extends for about $200 \mathrm{Km}$ in length, with average width $40-50 \mathrm{~m}$ and average depth 2-3 m (Goher, 2015). It starts from Damietta Branch at El-Kanater El-Khayria city to the middle and the east of Delta heading north, parallel to the Damietta Branch until Mansoura city at site (T5). Then it extends to the east within Dakahlia Governorate to Manzalah city and branched at Mansoura city to the east direction. The maximum discharge of El Tawfiki is $18.56 \mathrm{M} . \mathrm{m}^{3} /$ day (Fathy et al., 2013). This Rayah is characterized by existence of many drinking water stations and electric power plants on the two banks e.g. Banha drinking water station and other small water stations were used for villages, ezzabs and small towns which are heavily scattered on both sides of El Rayah. Water samples were collected from the beginning, middle and the end of El Rayah El Tawfiki at Mansoura, Dekerness and Manzalah cities, at sites (T1-T7) as shown in Table (1) and Figure (1).

\subsection{El Rayah El Menoufy:}

El-Rayah El Menoufy (about $170 \mathrm{Km}$ in length with width $\sim 50 \mathrm{~m}$ and depth $\sim 3 \mathrm{~m}$ ) starts from Rosetta Branch at El-Kanater El-khayria city and extends into the middle of Delta, breaking at Monifia, Dakahlia and El Gharbiah governorates, then heading north to Gamasa city and the south of Burullus Lake (Goher, 2015). El Rayah El Menoufy is characterized by the large number of small branches especially at El Monfia. At Zifta city (St. M5) a connected canal bearing large quantities of water from Damietta Branch discharge. The maximum discharge of El Rayah El Menoufy is $25 \mathrm{M} . \mathrm{m}^{3} /$ day (Fathy et al., 2013). Water samples were taken from 7 sites (M1-M7) at El-Rayah El Menoufy (Table 1 and Fig. 1). 
Howayda H. Abd El-Hady

Table 1. Sampling sites at EI Rayah El Tawfiki and El Rayah El Menoufy.

\begin{tabular}{|c|c|c|c|c|c|c|}
\hline & Sites & Name & Latitude & Longitude & $\begin{array}{l}\text { Distance from } \\
\text { El-Kanater } \\
(\mathbf{K m})\end{array}$ & Description \\
\hline \multirow{7}{*}{ 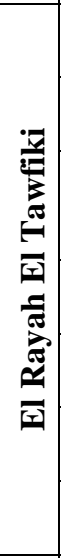 } & T1 & El-Kanater & $30^{\circ} 11^{\prime} 46.58^{\prime \prime}$ & $31^{\circ} 7{ }^{\prime} 55.98^{\prime \prime}$ & $1-1.5$ & $\begin{array}{l}\text { After line for railway line /very fast water } \\
\text { /receives few wastewater. }\end{array}$ \\
\hline & $\mathbf{T} 2$ & Banha & $30^{\circ} 28^{\prime} 24.0^{\prime \prime}$ & $31^{\circ} 12^{\prime} 1.04^{\prime \prime}$ & 40 & $\begin{array}{l}\text { In the front of Banha water plants /residential } \\
\text { region in the right and left sides. }\end{array}$ \\
\hline & T3 & Met gamer & $30^{\circ} 41^{\prime} 35.3^{\prime \prime}$ & $31^{\circ} 16 ' 50.2^{\prime \prime}$ & 70 & 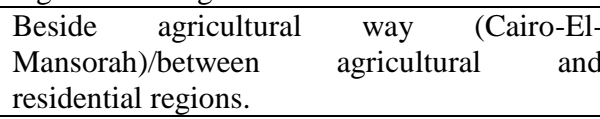 \\
\hline & T4 & Agga & $30^{\circ} 54^{\prime 23.12 "}$ & $31^{\circ} 16^{\prime} 51.88^{\prime \prime}$ & 100 & $\begin{array}{l}\text { Agricultural and residential regions in the right } \\
\text { and left sides. }\end{array}$ \\
\hline & T5 & Mansoura & $31^{\circ} 04^{\prime} 02.84 "$ & $31^{\circ} 25^{\prime} 02.13^{\prime \prime}$ & 130 & $\begin{array}{l}\text { Before branching of } \mathrm{El} \mathrm{Rayah/} \mathrm{between} \\
\text { agricultural and residential regions. }\end{array}$ \\
\hline & T6 & Dekerness & $31^{\circ} 5^{\prime} 38.65^{\prime \prime}$ & $31^{\circ} 37^{\prime} 37.77^{\prime \prime}$ & 155 & $\begin{array}{l}\text { Residential region in the west side and } \\
\text { agricultural region in east side/low water level. }\end{array}$ \\
\hline & T7 & El-Manzalah & $31^{\circ} 09^{\prime} 49.9^{\prime \prime}$ & $31^{\circ} 56^{\prime} 09.5^{\prime \prime}$ & 185 & $\begin{array}{l}\text { Static water/ receives the residues and wastes } \\
\text { of El Rayah. }\end{array}$ \\
\hline \multirow{7}{*}{ 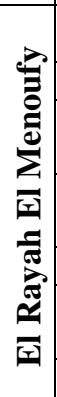 } & M1 & El-Kanater & $30^{\circ} 11 ' 59.85^{\prime \prime}$ & $31^{\circ} 66^{\prime} 44.97 "$ & 1 & Behind NIOF / receives few wastewater. \\
\hline & M2 & El-Khadra & $30^{\circ} 20^{\prime} 15^{\prime \prime}$ & $31^{\circ} 02^{\prime} 55^{\prime \prime}$ & 30 & Middle of agricultural and residential regions. \\
\hline & M3 & $\begin{array}{l}\text { Shebeen El- } \\
\text { Koum }\end{array}$ & $30^{\circ} 32^{\prime} 04.3^{\prime \prime}$ & $31^{\circ} 00^{\prime} 48.3^{\prime \prime}$ & 60 & Receives the water from Damietta Branch. \\
\hline & M4 & El-Santa & $30^{\circ} 43^{\prime} 44.50^{\prime \prime}$ & $31^{\circ} 7^{\prime} 28.88^{\prime \prime}$ & 100 & $\begin{array}{l}\text { Under bridge/slaw water flow/ receives large } \\
\text { amount of wastewater. }\end{array}$ \\
\hline & M5 & Zifta & $30^{\circ} 47^{\prime 2} 26.15^{\prime \prime}$ & $31^{\circ} 9^{\prime} 16.12 "$ & 130 & Receives the water from Damietta Branch \\
\hline & M6 & El-Mahalla & $30^{\circ} 566^{\prime} 59.4 "$ & $31^{\circ} 09^{\prime} 21.4^{\prime \prime}$ & 155 & $\begin{array}{l}\text { Middle of residential regions / receives few } \\
\text { wastewater. }\end{array}$ \\
\hline & M7 & Belqas & $31^{\circ} 07^{\prime} 59.9^{\prime \prime}$ & $31^{\circ} 22^{\prime} 50.1^{\prime \prime}$ & 185 & Middle of agricultural regions. \\
\hline
\end{tabular}

\section{Phytoplankton biochemical constituents and particulate biopolymeric organic carbon (BPC) analysis:}

Water samples were collected and filtered through zooplankton net $(100 \mu \mathrm{m}$ mesh size $)$ to separate macrozooplankton. The filtered water was refiltered on Whatman GF/F $(0.7 \mu \mathrm{m}$ pore diameter) fiber circles and the separated phytoplankton samples were transferred to the laboratory in ice tanks to determine their biopolymeric carbon (BPC). The total protein content was determined by Biuret method using bovine albumin as standard (David and Hazel, 1993). Carbohydrate contents were measured according to Phenol sulphuric acid hydrolysis method as described by Dubois et al. (1956), employing glucose as standard. Whereas the total lipid content was estimated by the Sulphophosphovanillin procedure utilizing cholesterol as calibration standard (Chabrol and Castellano, 1961). Phytoplankton caloric content was measured from the proximate biochemical composition, the relative caloric coefficients for proteins, carbohydrates and lipids were 5.56, 4.1 and 9.45 (Vollenweider, 2000). Concentrations of proteins, carbohydrates and lipids were converted to carbon equivalents using $0.40,0.49$ and $0.75 \mathrm{mgC} / \mathrm{l}$ conversion factors, respectively (Fabiano and Danovaro, 1994). The sum of protein carbon, carbohydrate $\mathrm{C}$ and lipid $\mathrm{C}$ is referred to as biopolymeric carbon (BPC) according to Fichez (1991) and Fabiano et al. (1995). The data of carbonate and bicarbonate were cited from Goher (2015) through the project of environmental status of the Nile Rayahs, Egypt. 


\section{RESULTS AND DISCUSSION}

Phytoplankton is responsible for about $50 \%$ of global primary production (Falkowski and Raven, 2007). The nutritional quality of phytoplankton available for aquatic herbivores depends mainly on their composition of lipid, protein and carbohydrate, which are affected by the changes in carbon as important environmental factors (Finkel et al., 2010). The present results illustrated that phytoplankton proteins exceeded in their values at most El Rayah El Tawfiki investigated sites $(\mathrm{Av} .=22.22 \mathrm{mg} / \mathrm{l})$ than River Nile $(19.92 \mathrm{mg} / \mathrm{l})$ except at stations (2 and 7) which represent the minimum contents of phytoplankton proteins (Table 2). Basiouny et al. (2008) illustrated that El-Rayah El Tawfiki and River Nile had almost the same $\mathrm{pH}$, total dissolved solids and conductivity, which are in acceptable range, but more organic than that of River Nile, due to higher values of turbidity, total organic carbon (TOC) and humic acid. The values of phytocarbohydrates at El Rayah El Tawfiki ranged between 0.2 and $0.67 \mathrm{mg} / \mathrm{l}$ which is less than that obtained at River Nile $(1.37 \mathrm{mg} / \mathrm{l})$. The lipid peaked $(0.41 \mathrm{mg} / \mathrm{l})$ at st. (T5) as shown in Table (2). Particulate biopolymeric organic carbon (BPC) along El Rayah El Tawfiki (4.32-18.59 $\mathrm{mgC} / \mathrm{l})$ was associated to the high extent biopolymeric $\mathrm{C}$ of proteins (4.73-18.36 $\mathrm{mgC} / \mathrm{l})$. Synthesis of algal particulate organic carbon (POC) which is particulate protein amino acid (PPAA) carbon depends on carbon concentrations in the medium (Lohrenz et al., 1987).

The present results indicated that there was a significant relationship $(\mathrm{p} \leq 0.05)$ between in situ measurements of both $\mathrm{CO}_{3}$ and $\mathrm{HCO}_{3}$ and $\mathrm{BPC}$ of phytoplankton $\left(\mathrm{r}^{2}=0.822\right.$ and 0.842 , respectively) in El Rayah El Tawfiki. While results of biopolymeric $\mathrm{C}$ of carbohydrates was ranged between $0.08-0.27 \mathrm{mgC} / 1$. Carbohydrates are usually related to organic matter preeminently refractory in nature (Grémare et al., 2003; Pusceddu et al., 2009). The importance of the different biochemical contents of biopolymeric carbon might give information about the source and fate of sediment organic matter (Pusceddu et al., 2000; Fabiano et al. 2001).

Seasonal variations of phytoplankton biopolymeric $\mathrm{C}$ at El Tawfiki indicated that summer was the optimum for BPC of both proteins and carbohydrates (10.97 and $0.24 \mathrm{mgC} / \mathrm{l}$, respectively), which may be related to higher $\mathrm{CO}_{3}(\mathrm{Av} .=8.64 \mathrm{mg} / \mathrm{l})$. The highest carbohydrate contents of phytoplankton at Ismailia Canal were recorded in summer (Abd El-Hady and Hussian, 2012).

Table 2. Features of phytoplankton at El Rayah El Tawfiki based on carbon sequestration in proteins, carbohydrates, lipids and the particulate biopolymeric organic carbon (BPC).

\begin{tabular}{|l|c|c|c|c|c|c|c|}
\hline $\begin{array}{c}\text { Sampling } \\
\text { sites }\end{array}$ & $\begin{array}{c}\text { Proteins } \\
\text { (mg/l) }\end{array}$ & $\begin{array}{c}\text { Biopolymeric } \\
\text { C equivalent } \\
\text { of proteins } \\
\text { (mgC/l) }\end{array}$ & $\begin{array}{c}\text { Carbohydrates } \\
\text { (mg/l) }\end{array}$ & $\begin{array}{c}\text { Biopolymeric C } \\
\text { equivalent of } \\
\text { carbohydrates } \\
\text { (mgC/l) }\end{array}$ & $\begin{array}{c}\text { Lipids } \\
(\mathbf{m g} / \mathbf{l})\end{array}$ & $\begin{array}{c}\text { Biopolymeric C } \\
\text { equivalent of } \\
\text { lipids (mgC/l) }\end{array}$ & $\begin{array}{c}\text { particulate } \\
\text { biopolymeric } \\
\text { organic carbon } \\
\text { (BPC) }\end{array}$ \\
\hline RN & 19.92 & 9.76 & 1.37 & 0.55 & 0.37 & 0.28 & 10.59 \\
\hline T 1 & 26.91 & 13.19 & 0.40 & 0.16 & 0.24 & 0.18 & 13.53 \\
\hline T 2 & 9.66 & 4.73 & 0.60 & 0.24 & 0.32 & 0.24 & 5.21 \\
\hline T 3 & 25.13 & 12.31 & 0.43 & 0.17 & 0.35 & 0.26 & 12.74 \\
\hline T 4 & 25.44 & 12.47 & 0.67 & 0.27 & 0.30 & 0.22 & 4.32 \\
\hline T 5 & 19.16 & 9.39 & 0.42 & 0.17 & 0.41 & 0.31 & 9.87 \\
\hline T 6 & 37.47 & 18.36 & 0.30 & 0.12 & 0.15 & 0.11 & 18.59 \\
\hline T 7 & 11.76 & 5.76 & 0.20 & 0.08 & 0.23 & 0.17 & 6.01 \\
\hline Av. & 21.93 & 10.89 & 0.55 & 0.17 & 0.30 & 0.21 & 11.27 \\
\hline
\end{tabular}

There were a fluctuation in the results of proteins and lipids along El Rayah El Menoufy, where st. (M6) represents the optimum yield of both proteins and lipids, 29.87 and $0.55 \mathrm{mg} / 1$, 
which may be due to the increase of nutrients as a result of few wastewater discharge, whereas there was an obvious decrease in carbohydrate contents at all sites of El Menoufy than River Nile (Table 3). On the other hand, winter was the optimum for the determined biopolymeric carbon at El Rayah El Menoufy (10.91, 0.31 and $0.39 \mathrm{mgC} / 1$ for proteins, carbohydrates and lipids, respectively). The elevation in BPC in winter may be attributed to the increase of $\mathrm{HCO}_{3}(150.16$ $\mathrm{mg} / \mathrm{l}$ ). Algae can grow autotrophically utilizing the $\mathrm{HCO}_{3}{ }^{-}$and even $\mathrm{CO}_{3}{ }^{2-}$ ion directly (Becker, 1994). Lipids responsible for oxidation processes of providing energy, through $-\mathrm{C}=\mathrm{O}$ - bounds, than other biochemical compounds (Boëchat and Giani, 2000). Lipids constitute an important fraction of particulate OM in aquatic environments (Borsheim et al., 1999; Burdige et al., 2000). The results of the present study of total concentration of BPC along El Rayah El Menoufy ranged from 6.19 to $15.42(\mathrm{mgC} / \mathrm{l})$. The higher concentration of $\mathrm{BPC}$ at M6 related to increase biopolymeric carbon in both proteins and lipids (14.64 and $0.41 \mathrm{mgC} / \mathrm{l})$ at this site. Proteins represent a significant portion of organic matter (Salas et al., 2015). Triacylglycerols (TAGs) or neutral lipids represent $\sim 60 \%$ of the total dry weight of algae, more than $75 \%$ of the mass of TAGs is carbon, and thus TAGs represent rich sources of captured carbon in cells.

Data analyses illustrated that $\mathrm{CO}_{3}$ is related significantly to lipids and $\mathrm{BPb}$ of phytoplankton at El Rayah El Menoufy $\left(\mathrm{r}^{2}=0.633\right.$ and 1.00 , respectively), while $\mathrm{HCO}_{3}$ related to proteins, lipids and $\mathrm{PBb}\left(\mathrm{r}^{2}=0.999,0.652\right.$ and 1.00 , respectively). High incorporation of carbon into algal lipids occurred under nitrogen-deficient environment or during stationary growth phases of phytoplankton, whereas in nitrogen sufficient water carbon was highly incorporated into proteins (Lee et al., 2009).

Table (3). Features of phytoplankton at El Rayah El Menoufy based on carbon sequestration in proteins, carbohydrates, lipids and the particulate biopolymeric organic carbon (BPC).

\begin{tabular}{|l|c|c|c|c|c|c|c|}
\hline $\begin{array}{c}\text { Sampling } \\
\text { sites }\end{array}$ & $\begin{array}{c}\text { Proteins } \\
(\mathbf{m g} / \mathbf{l})\end{array}$ & $\begin{array}{c}\text { Biopolymeric } \\
\text { C equivalent } \\
\text { of proteins } \\
\text { (mgC/l) }\end{array}$ & $\begin{array}{c}\text { Carbohydrates } \\
(\mathbf{m g} / \mathbf{l})\end{array}$ & $\begin{array}{c}\text { Biopolymeric C } \\
\text { equivalent of } \\
\text { carbohydrates } \\
\text { (mgC/l) }\end{array}$ & $\begin{array}{c}\text { Lipids } \\
(\mathbf{m g} / \mathbf{l})\end{array}$ & $\begin{array}{c}\text { Biopolymeric C } \\
\text { equivalent of } \\
\text { lipids (mgC/l) }\end{array}$ & $\begin{array}{c}\text { particulate } \\
\text { biopolymeric } \\
\text { organic carbon } \\
\text { (BPC) }\end{array}$ \\
\hline RN & 19.92 & 9.76 & 1.37 & 0.55 & 0.37 & 0.28 & 10.59 \\
\hline M 1 & 12.12 & 5.93 & 0.33 & 0.13 & 0.18 & 0.13 & 6.19 \\
\hline M 2 & 16.13 & 7.90 & 0.33 & 0.13 & 0.34 & 0.26 & 8.29 \\
\hline M 3 & 21.26 & 10.42 & 0.30 & 0.12 & 0.33 & 0.25 & 10.79 \\
\hline M 4 & 21.65 & 10.60 & 0.70 & 0.28 & 0.34 & 0.26 & 11.14 \\
\hline M 5 & 26.57 & 13.02 & 1.00 & 0.40 & 0.47 & 0.35 & 13.77 \\
\hline M 6 & 29.87 & 14.64 & 0.48 & 0.19 & 0.55 & 0.41 & 15.24 \\
\hline M 7 & 22.42 & 10.99 & 0.40 & 0.16 & 0.20 & 0.15 & 11.30 \\
\hline Av. & 21.24 & 10.50 & 0.61 & 0.20 & 0.35 & 0.26 & 10.96 \\
\hline
\end{tabular}

Variations in the estimated biochemical components of phytoplankton in the two Nile Rayahs followed the trend: Proteins $>$ carbohydrates $>$ lipids which indicated the highest protein contribution to $\mathrm{C}-\mathrm{BPC}$ in the studied regions. Lipid/carbohydrates ratio in the two studied Rayahs ranged between 0.55 and 0.57 , which showed high nutritional value of $\mathrm{OM}$ in phytoplankton. Lipids/carbohydrates ratio was used as a food quality index of OM (Gremare et al., 2002). Proteins/carbohydrates ratio in phytoplankton of the two Rayahs was 43.82-39.88, which indicated the aging of organic matter in phytoplankton (Salas et al., 2015). In phytoplankton amino acids occupied about $67 \%$ of organic carbon, while carbohydrates and lipids contain about 4\% and 15\%, respectively (Lee et al., 2000; Wakeham et al., 2000). 
The caloric values of phytoplankton at the two studied regions have convergent values, where El Rayah El Tawfiki recorded the highest energetic value $(127.86 \mathrm{Kcal} / \mathrm{l})$ than that at El Menoufy (124.45 Kcal/l) as shown in Figure (2). The environmental variables interacted with the observed variations in energy content of the phytoplankton in fresh water lake, the quality of phytoplankton varied with energy content in the engulfing phytoplankton (Chattopadhyay, 2014).

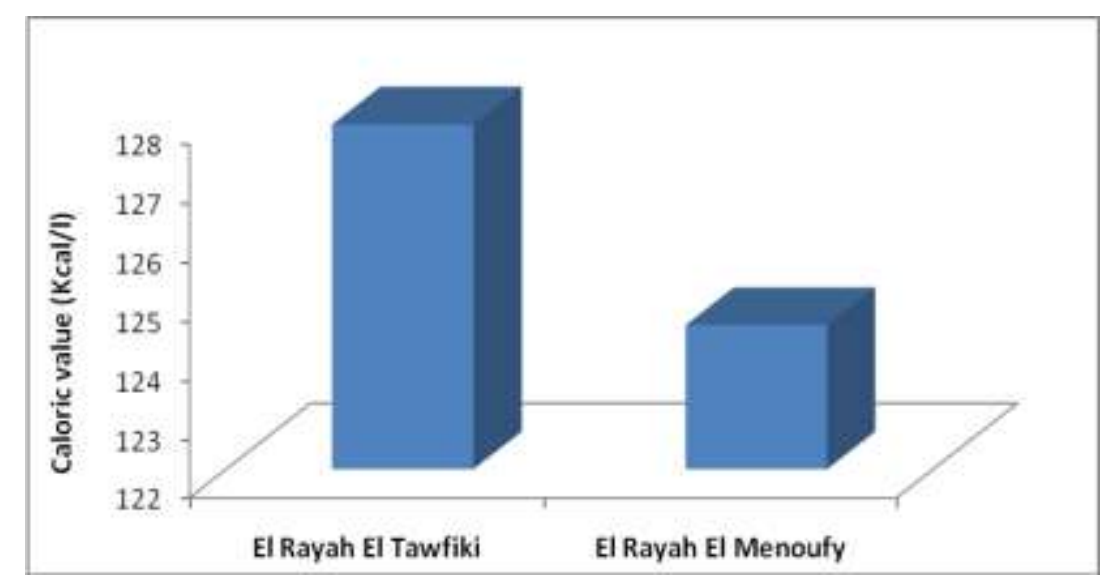

Fig. (2). Energetic value of phytoplankton (Kcal/I) at the two Nile Rayahs.

Canonical correspondence analysis (CCA) biplot diagram at the studied Nile Rayahs indicated that $\mathrm{CO}_{3}{ }^{2-}$ and $\mathrm{HCO}_{3}{ }^{-}$have high effect on carbon captured by biochemical variables, where they recorded a high positive correlation with phytoplankton BPC, where $\mathrm{r}=0.9$ and 1 of El Rayahs El Tawfiki and El Menofy, respectively. A negative correlation with carbon equivalent of protein and carbohydrate were detected (Fig. 3). The analyses data suggested that increased carbon availability changes the biochemistry composition and thus nutritional quality and BPC of individual phytoplankton.

Microalgae is efficient to capture carbonate or bicarbonate as high as $90 \%$ in open ponds to fertilize algal growth (Sayre, 2010). One gram of algal biomass is produced by captured of 1.6-2.0g of carbon (Herzog and Golomb, 2004). Cyanobacteria and eukaryotic algae transport and use bicarbonate as a source of carbon dioxide (Spalding 2008: Jansson and Northen, 2010). The concentrations and biochemical composition of phytoplankton were pools of suspended organic particles in both studied El Rayahs. A positive relationship has been observed between BPC of phytoplankton and the fraction of biopolymeric $\mathrm{C}$ associated with phytoproteins $(\mathrm{r}=$ 0.79). The study of Pusceddu et al. (2010) confirmed that the primary productivity was a major factor controlling both quantity and nutritional quality of phytoplankton organic matter. 
Howayda H. Abd El-Hady

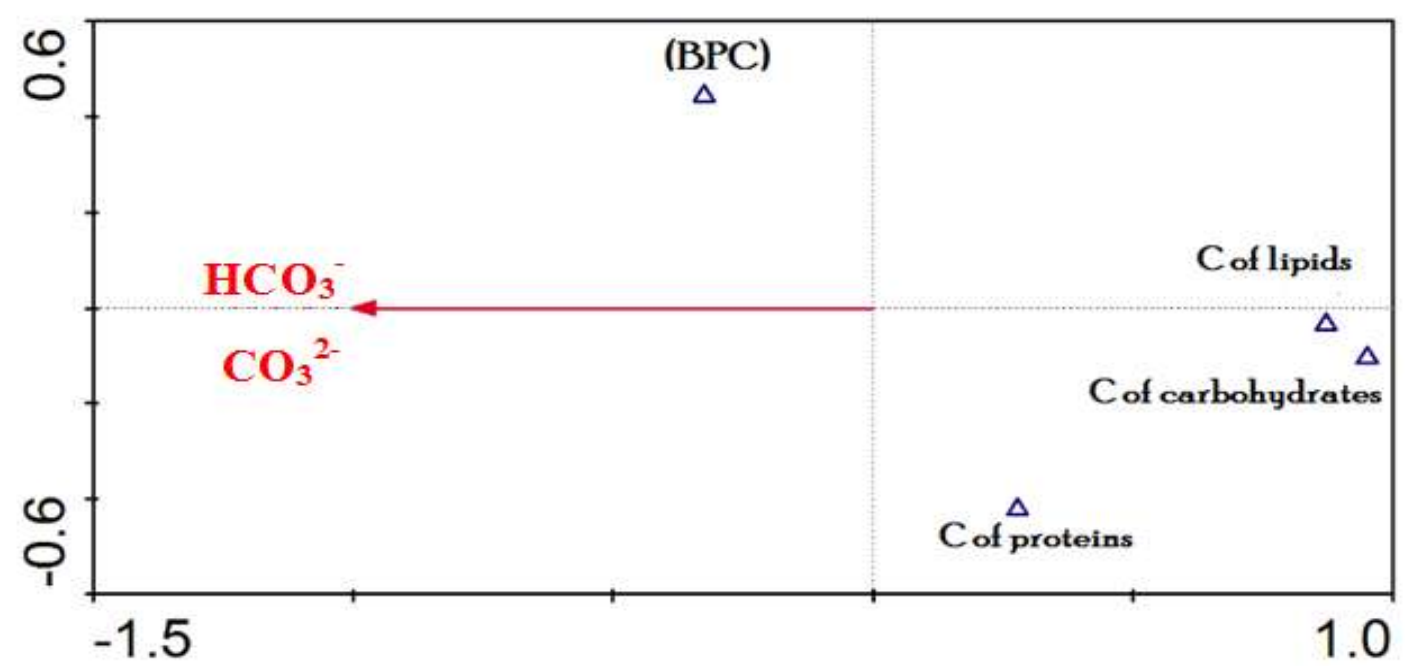

Fig. (3). Canonical Correspondence Analysis (CCA) for analyzed carbonate and bicarbonate with biopolymeric carbon in protein, carbohydrate, lipids and particulate biopolymeric organic carbon (BPC) of phytoplankton at the studied Nile Rayahs.

\section{CONCLUSION AND RECOMMENDATION}

The study indicated that the particulate biopolymeric organic carbon (BPC) of microalgae provides additional information on the origin, quality and characteristics of the organic matter available for food chain in El-Rayahs El Tawfiki and El Menofy of the River Nile. The results demonstrated that fluctuation in phytoplankton composition due to the changes of carbonate and bicarbonate concentrations will have more impact on nutritional quality and BPC of phytoplankton. More research in the field of molecular biology is needed to provide more information about the microalgae involved in production and recycling of carbon in fresh water environment.

\section{ACKNOWLEDGMENT:}

The author is grateful to Inland Water and Aquaculture Branch, National Institute of Oceanography and Fisheries, Cairo, Egypt which funded this work through a project entitled "The environmental status of the Nile Rayahs, Egypt". The author also expresses her sincere thanks to Dr. Mohamed E. Goher for providing carbonate and bicarbonate data.

\section{REFERENCES}

Abd El-Hady, H.H. and Hussian, A.M. (2012). Regional and seasonal variation of phytoplankton assemblages and its biochemical analysis in Ismailia canal, River Nile, Egypt. J. Appl. Sci. Res., 8(7): 3433-3447

Akhil, P.S.; Manju, P.N. and Sujatha, C.H. (2013). Core sediment biogeochemistry in specific zones of Cochin Estuarine System (CES). J. Earth. Syst. Sci., 122: 1557-1570.

Armstrong, R.A.; Lee, C.; Hedges, J.I.; Honjo, S. and Wakeham, S.G. (2002). A new mechanistic model for organic carbon fluxes in the ocean based on the quantitative association of POC with ballast minerals. Deep-Sea Res. II, 49: 219-236.

Basiouny, M.; Fouad, E.A.; Elmitwalli, T. and Abu-Elkhair, N.Y. (2008). Twelfth International Water Technology Conference, IWTC12 2008, Alexandria, Egypt. 979-989. 
21

\section{Evaluation of biopolymeric particulate organic carbon of phytoplankton from El Rayah EI Tawfiki and El Rayah El Menoufy of Nile Delta, Egypt}

Becker, E.W. (1994). Microalgae biotechnology and microbiology. Cambridge University Press, London.

Boëchat, I.G. and Giani, A. (2000). Factors affecting biochemical composition of seston in an eutrophic reservoir (Pampulha Reservoir, Belo Horizonte, MG). Rev. Bras. Biol., 60(1): 63-71.

Borsheim, K.Y.; Myklestad, S.M.; Sneli, J.A. (1999). Monthly profiles of DOC, mono and poly saccharides at two locations in the Trondheimsfjords (Norway) during two years. Mar. Chem., 63: 255-272.

Burdige, D.J.; Skoog, A. and Gardner, K. (2000). Dissolved and particulate carbohydrates in contrasting marine sediments. Geochim. Cosmochim. Acta., 64: 1029-1041.

Chabrol, E. and Castellano, A. (1961). SPV method for estimation of total serum lipid. J. Lab. Clin. Med., 57: 300.

Chattopadhyay, C. (2014). Polyphenolics and Energy Content in Phytoplankton: Evidence from a Freshwater Lake. Proc. Zooplankton Soc., 67: 18-27.

Cividanes, S.; Incera, M. and Lopez, J. (2002). Temporal variability in the biochemical composition of sedimentary organic matter in an intertidal flat of the Galician coast (NW Spain). Oceanol. Acta, 25: 1- 12.

Cloern, J.E. (2001). Our evolving conceptual model of the coastal eutrophication problem. Mar. Ecol. Prog. Ser., 210: 223-253.

Colombo, J.C.; Silverberg, N. and Gearing, J.N. (1996). Biogeochemistry of organic matter in the Laurentian trough, II. Bulk composition of the sediments and relative reactivity of major components during early diagenesis. Mar. Chem., 51: 295-314.

David, J.H. and Hazel, P. (1993). Analytical biochemistry. Hand Book, $18 \mathrm{ed}$.

Dell'Anno, A.; Mei, M.L.; Pusceddu, A. and Danovaro, R. (2002). Assessing the trophic state and eutrophication of coastal marine systems. A new approach based on the biochemical composition of sediment organic matter. Mar. Pollut. Bull., 44: 611-622.

Dubois, M.; Gilles, K.A.; Hamilton, J.K.; Rebers, P.A. and Smith, F. (1956). Colorimetric method for the determination of sugars and related substances. Anal. Chem., 28:350356.

Fabiano, M. and Danovaro, R. (1994). Composition of organic matter in sediments facing a river estuary (Tyrrhenian Sea): relationships with bacteria and microphytobenthic biomass. Hydrobiologia, 277: 71-84.

Fabiano, M.; Danovaro, R. and Fraschetti, S. (1995). Temporal trend analysis of the elemental composition of the sediment organic matter in subtidal sandy sediments of the Ligurian Sea (NW Mediterranean): A three years study. Cont. Shelf. Res., 15: 1453-1469.

Fabiano, M.; Pusceddu, A.; Dell'Anno, A.; Armeni, M.; Vanucci, S.; Lampitt, R.S.; Wolff, G.A. and Danovaro, R. (2001). Fluxes of phytopigments and labile organic matter to the deep ocean in the NE Atlantic Ocean. Prog. Oceanogr., 50: 89-104.

Falkowski, P.G. and Raven, J.A. (2007). Aquatic Photosynthesis. Princeton University Press, Princeton.

Fathy, I.H.; El-Belasy, A.; Helal, Y.E. and Sobeih, M.F. (2013). Effect of Main Barrages Failure on the Nile Valley. Nile Basin Water Science and Engineering Journal, 6(2): 76-87.

Fichez, R. (1991). Composition and fate of organic matter in submarine cave sediments; implications for the biogeochemical cycle of organic carbon. Oceanol. Acta., 14: 369377. 


\section{Howayda H. Abd El-Hady}

Finkel, Z.V.; Beardal, J.L; Flynn, K.J.; Quigg, A.; Rees, T.A.V. and Raven, J.A. (2010). Phytoplankton in a changing world: cell size and elemental stoichiometry. J. Plankton. Res., 32 (1): 119-137

Ghannam, H.E.; El Haddad, E.S.E. and Talab, A.S. (2015). Bioaccumulation of heavy metals in tilapia fish organs. J. Bio. and Env. Sci., 7(2): 88-99.

Goher, M.E. (2015). The environmental status of the Nile Rayahs, Egypt. Final Report, National Institute of Oceanography and Fisheries (NIOF), Egypt (not published).

Goni, M.A.; Maria, J.T. and David, W.P. (2003). Sources and distribution of organic matter in a river-dominated estuary (Winyah Bay, SC, USA). Estuar. Coast. Shelf Sci., 57: 10231048.

Gremare, A.; Medernach, L.; deBovée, F.; Amoroux, J.M.; Vétion, G. and Albert, P. (2002). Relationships between sedimentary organics and benthic meiofauna on the continental shelf and the upper slope of the Gulf of Lions (NW Mediterranean). Mar. Ecol. Prog. Ser., 234: 85-94.

Grémare, A.; Amouroux, J.M.; Cauwet, G.; Charles, F.; Courties, C.; De Bovée, F.; Dinet, A.; Devenon, J.L.; Durrieu, D.X.; Ferre, B.; Fraunie, P.; Joux, F.; Lantoine, F.; Lebaron, P.; Naudin, J.J.; Palanques, A.; Pujo-Pay, M. and Zudaire, L. (2003). The effects of a strong winter storm on physical and biological variables at a shelf site in the Mediterranean. Oceanol. Acta., 26:407-419.

Herzog, H. and Golomb, D. (2004). Carbon capture and storage from fossil fuel use. Encyclopedia of Energy, 1: 1-11.

Jansson, C. and Northen, T. (2010). Calcifying cyanobacteria-the potential of biomineralization for carbon capture and storage. Curr. Opin. Biotechnol., 21: 1-7.

Joseph, M. M.; Ratheesh, K.C.S.; Gireesh, K.T.R.; Renjith, K.R. and Chandramohanakumar, N. (2008). Biogeochemistry of surficial sediments in the intertidal systems of a tropical environment. Chem. Ecol., 24: 247-258.

Lee, C.; Wakeham, S.G. and Hedges, J.I. (2000). Composition and flux of particulate amino acids and chloropigments in equatorial Pacific seawater and sediments. Deep-Sea Res. I., 47: 1535-1568.

Lee, S.H.; Kim, H. and Whitledge, T.E. (2009). High incorporation of carbon into proteins by the phytoplankton of the Bering Strait and Chukchi Sea. Cont. Shelf Res., 29: 1689-1696.

Lohrenz, S.E.; Taylor, C.D. and Howes, B.L. (1987). Primary production of protein: 11. Algal protein metabolism and its relation to particulate organic matter composition in the surface mixed layer. Mar. Ecol. Prog. Ser., 40: 175-183.

Pusceddu, A.; Bianchelli, S.; Canals, M.; Sanchez-Vidal, A.; De Madron, X.D.; Heussner, S.; Lykousis, V.; Stigter, H.; Trincardi, F. and Danovaro, R. (2010). Organic matter in sediments of canyons and open slopes of the Portuguese, Catalan, Southern Adriatic and Cretan Sea margins. Deep-Sea Res. I., 57: 441-457.

Pusceddu, A.; Dell'Anno, A. and Fabiano, M. (2000). Organic matter composition in coastal sediments at Terra Nova Bay (Ross Sea) during summer 1995. Polar Biol., 23: 288-293.

Pusceddu, A.; Dell'Anno, A.; Fabiano, M. and Danovaro, R. (2009). Quantity and bioavailability of sediment organic matter as signatures of benthic trophic status. Mar. Ecol. Progr. Ser., $375: 41-52$

Renjith, K.R.; Manju, M.J.; Prosenjit, G.K.; Habeeb, R.; Ratheesh, K.C.S. and Chandramohanakumar, N. (2013). Biogeochemical facsimile of the organic matter 
quality and trophic status of a micro-tidal tropical estuary. Environ. Earth. Sci., 70(2): 729-742.

Rossi, F. and Lardicci, C. (2002). Role of the nutritive value of sediment in regulating population dynamics of the deposit-feeding polychaete Streblospio shrubsolii. Mar. Biol., 140: 1129-1138.

Salas, P.M.; Sujatha, C.H. and Ratheesh Kumar, C.S. (2015). Fate and source distribution of organic constituents in a river dominated tropical estuary. J. Earth Syst. Sci., 124(6): 1265-1279.

Sayre, R. (2010). Microalgae: The Potential for Carbon Capture. BioScience, 60(9): 722-727.

Shawky, Y.; Nada, A.M. and Abdelhaleem, F.S. (2013). Environmental and hydraulic design of thermal power plants outfalls "Case study: Banha Thermal Power Plant, Egypt'. Ain Shams Engineering J., 4: 333-342.

Spalding, M.H. (2008). Microalgal carbon-dioxide-concentrating mechanisms: Chlamydomonas inorganic carbon transporters. J. Exp. Bot., 59: 1463-1473.

Sudhakar, K. and Premalatha, M. (2012). Theoretical Assessment of Algal Biomass Potential for Carbon Mitigation and Biofuel Production. Iranica J. Energy and Environ., 3(3): 232240.

Talab, A.S.; Goher, M.E.; Ghannam, H.E. and Abdo, M.H. (2016). Chemical compositions and heavy metal contents of Oreochromis niloticus from the main irrigated canals (rayahs) of Nile Delta. Egypt. J. Aquat. Res., 42: 23-31.

Vollenweider, R.A. (2000). Concerning calculation methods and limitations of proxi-estimates of proteins, carbohydrates and lipids in crustacean zooplankton from $\mathrm{CHN}$ analyses: some comments. J. Limnol., 59(2): 170-178.

Wakeham, S.G.; Lee, C. and Hedges, J.I. (2000). Fluxes of major biochemicals in the Equatorial Pacific Ocean. p. 117- 140. In Dynamics and Characterization of Marine Organic Matter, ed. by H. Handa, E. Tanoue and T. Hama, Terra Sci. Publ., Tokyo/Kluwer Acad. Publ., Dordrecht.

Yamamuro, M. (2000). Chemical tracers of sediment organic matter origins in two coastal lagoons. J. Mar. Syst., 26: 127-134. 


\section{Howayda H. Abd El-Hady}

تقدير عنصر الكربون العضوي البوليمر داخل الهائمات النباتيه فى كلا"من الرياح التوفيقى والرياح المنوفى لالتا النيل، مصر هويدا حسان عبد الهادى الهمادي

المعهد القومى لعلوم البحار والمصايد، 101 القصر العينى، القاهره، مصر

\section{المستخلص}

تناولت الدر اسه قياس الكربون العضوى البوليمر (BPC) من حيث التركيز و التكوين داخل الهائمات النباتيه لرياحيين

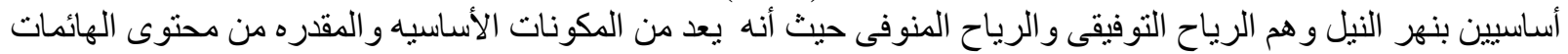

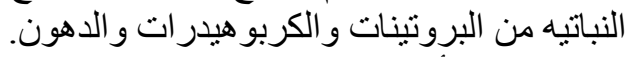

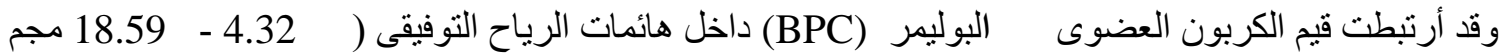

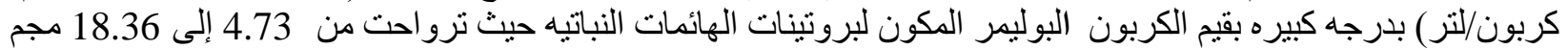

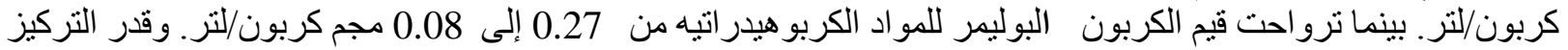

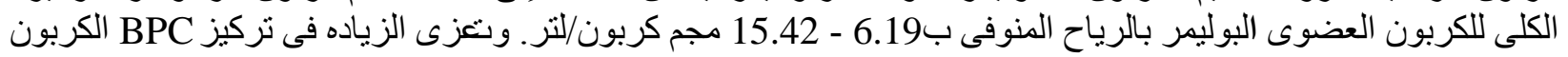

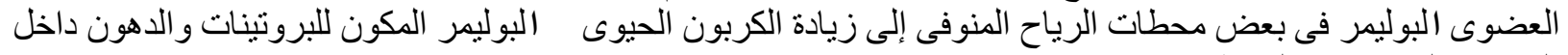
الهائمات النباتيه بهذه الئولير فحطات.

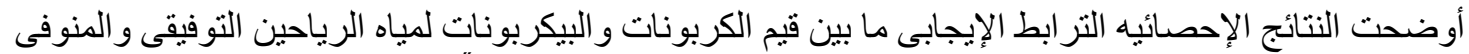

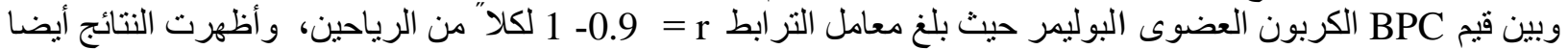

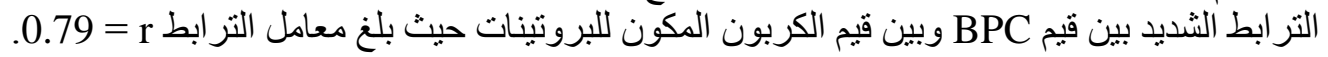

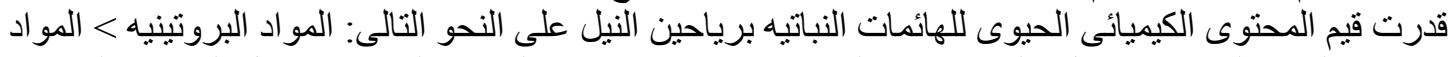

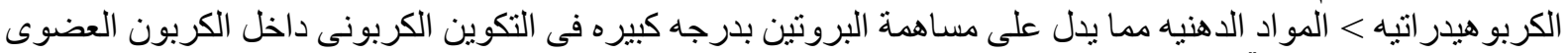

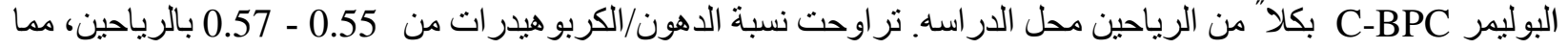

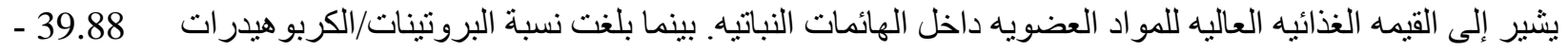

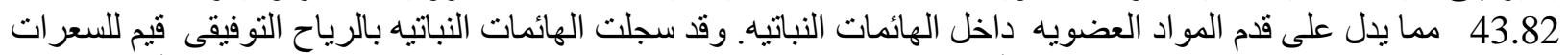

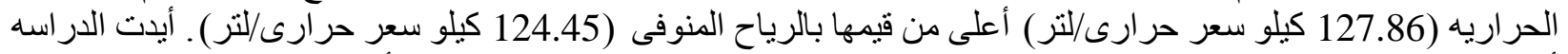

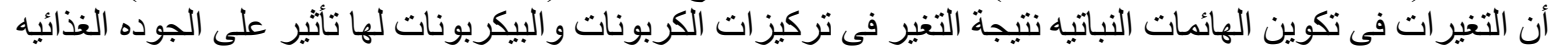
و الكربون العضوى البوليمر (BPC) للهائمات. 